\title{
Antecedents and Outcomes of Brand Love: Utilitarian and Symbolic Brand Qualities
}

Cristela Maia Bairrada; Filipe Coelho; Arnaldo Coelho

Faculty of Economics and Centre for Business and Economics Research, University of Coimbra, Coimbra, Portugal

The final version of this article is available online at https://www.emeraldinsight.com/doi/pdfplus/[https://doi.org/10.1108/EJM-02-2016-0081 ]

This manuscript version is made available under the Creative Commons Attribution Noncommercial International Licence 4.0 (CC BY-NC 4.0). Reuse is allowed in accordance with the terms outlined by this licence. 


\section{Introduction}

Brands have become an integral part of consumers' lives. In particular, research acknowledges that consumers may look at brands as relationship partners (e.g., Breivik \& Thorbjørnsen, 2008; Moliner, Sánchez, Rodríguez, \& Callarisa, 2007). In this regard, Fournier (1998, p. 367) noted that "brands cohere into systems that consumers create not only to aid in living but also to give meaning to their lives. Put simply, consumers do not choose brands, they choose lives". In this vein, research has shown that people, apart from loving other people, can also love objects, namely brands (Ahuvia, Batra, \& Bagozzi, 2009).

Brand love is a relatively recent topic of research (e.g., Albert, Merunka, \& Valette-Florence, 2008; Batra, Ahuvia, \& Bagozzi, 2012). Ahuvia et al. (2009, p. 354-355) noted that "research on loved objects provides a spotlight for illuminating some of the most psychically significant consumption experiences. Love is an extreme experience, but not an aberrant one". Moreover, Homburg, Wieseke \& Hoyer (2009, p.49) argue that "in today's business environment, constructs other than customer satisfaction are needed to improve financial performance". Research on brand love and, more generally, on consumer-brand relationships (e.g., brand trust, brand attachment), signal that such consumer-brand linkages have important outcomes, including brand loyalty, positive word-of-mouth, and willingness to pay (e.g., Batra et al., 2012; Malar et al., 2011). In this context, appreciating the antecedents of brand love is extremely useful, since "a deeper understanding of how consumers feel, think, and act could provide valuable guidance to address" the challenges of brand-management (Keller, 2003, p. $595)$.

Moreover, the research in the area is plagued by different conceptualisations of brand love. Hence, the sparse studies that have looked at the antecedents of brand love and that have followed different conceptualisations are not directly comparable. This clearly signals that research exploring the antecedents of brand love, and that follows rigorous conceptualisations 
is urgently needed, so that brand managers can better ascertain how to enact such close relationships with customers and spur brand financial performance. Accordingly, by investigating the drivers of brand love we contribute to the understanding of those experiences that play a remarkable role in consumers' lives (Ahuvia, 2005). In particular, it has been noted that developing brands along such lines should contribute to more enduring competitive positions and, thus, to marketing success (see Thompson et al., 2006). Hence, with this knowledge managers will be better equipped to build their brands such that they become an integral part of consumers' lives.

We put forward a model of the antecedents of brand love in which we consider a set of previously-untested variables. To accomplish this, we draw on the information processing as well as on the experiential models of consumer behaviour, which guided the selection of variables for the study. Accordingly, the contribution of this paper lies in establishing how both more tangible, functional attributes, as well as more intangible, symbolic ones, relate to one another to end up contributing to the formation of brand love. These functional and symbolic qualities have differing levels of abstraction, which have guided model building. Though not the primary focus of this research, we also test some consequences of brand love in order to investigate whether the brand love construct differentiates from such outcomes, as well as to obtain evidence concerning the universality of such consequences.

\section{Research Background and Hypotheses}

\subsection{Brand Love: The Concept and its Importance}


Brands, as a relationship partner in consumer settings, have only gained research momentum in the last few years (Fetscherin \& Heinrich, 2015). This research movement follows Fournier's (1998) landmark paper on brand relationships. Since then, many constructs have emerged, all attempting to capture the nature of consumer brand relationships, such as brand attachment (e.g., Malar et al., 2011), brand communities (e.g. Marzocchi, Morandin, \& Bergami, 2013; Bagozzi \& Dholakia, 2006), and emotional branding (e.g., Thompson, Rindfleisch, \& Arsel, 2006). Brand love research dates back to Ahuvia (1992), but only gained research momentum in the past decade or so (Carroll and Ahuvia 2006). This largely confirms the view that consumers use consumption to build their identity (Ahuvia, 2005; Levy, 1959), using brands as "powerful repositories of meaning" (Fournier, 1998, p. 365). In particular, consumers perceive loved objects as part of themselves as well as of the world in which they live, with loved objects playing a significant role in building their world (Ahuvia et al, 2009). In this context, Ahuvia et al. (2009) observed that consumers perceived the objects they love as being integrated with their identity in those instances when they had an extensive shared history, when the brand expressed the self, affected or changed the person in some way, and/or constituted a physical extension of their brain or body. Thus, loved brands occupy a central role in people's lives.

Carroll and Ahuvia (2006, p. 81) defined brand love "as the degree of passionate emotional attachment a satisfied consumer has for a particular trade name". Subsequently, and amid the lack of consensual definitions and measures for brand love, Batra et al. (2012), proposed a prototype-based definition of brand love, following the idea that complex, fuzzy concepts, are best described by prototypes - a prototype approach involves the definition of a list of attributes that consumers typically associate with a certain concept (Fehr \& Russell, 1991). Batra et al. (2012) clearly position brand love as a type of relationship (rather than as an emotion) that 
consumers establish with brands, encompassing "multiple interrelated cognitive, affective, and behavioural elements, rather than a specific, single, transient love emotion" (Batra et al., 2012, p. 6), and that is characterised by the following attributes: 1) Passion-driven behaviours, meaning the consumer has a passionate involvement with the brand and desires to use it, has frequently interacted with the brand in the past, and has invested resources, including time and money, in the brand; 2) A positive emotional connection, relating to consumers' feelings that there is a natural fit between the brand and themselves, and experiencing an emotional connection and positive emotions with the brand; 3) Self-brand integration, denoting that consumers have frequent thoughts about the brand, which is perceived to express consumers' current and desired self-identity, also providing meaning to life; 4) Long-term relationship, meaning that consumers desire the brand to be part of their life for a long time; 5) Anticipated separation distress, reflecting how emotionally painful it would be for consumers if the brand were to cease existence; 6) Positive attitude valence, entailing an overall positive evaluation of the brand; and 7) Attitude strength, which concerns a high degree of certainty and confidence in the feelings a consumer holds about a focal brand.

The few studies that have investigated brand love, have determined that it has important outcomes, including loyalty and positive word-of-mouth (Albert et al., 2009; Batra et al., 2012). Albert et al. (2013) have also found brand passion to be related to brand commitment and wordof-mouth. These consequences suggest that identifying the antecedents of brand love should have important pay-offs.

\subsection{Past Research on the Antecedents of Brand Love}


Previous studies that have explored the antecedents of brand love using the approach suggested by Batra et al. (2012) have identified a few variables with predictive power, including brand quality (Batra et al., 2012; Rauschnabel \& Ahuvia, 2014), a utilitarian attribute, and brand anthropomorphism (Rauschnabel \& Ahuvia, 2014), brand experience, self-congruity (Bıçakcığlu et al., 2016), and brand personality (Rauschnabel et al., 2016), which are symbolic/experiential attributes. Additionally, there are a number of studies that rely on different brand love conceptualisations, which have identified other antecedents, including brand trust and brand identification (Albert et al., 2013), self-expressive brands and hedonic products (Carroll \& Ahuvia, 2006), sincerity and excitement (Roy et al., 2016), and social identity (Vernuccio et al., 2015). Roy et al. (2012), in a theoretical paper, discuss several antecedents of brand love, including satisfaction, self-congruity, consumer delight, romanticism, and brand experience. We note that some antecedents considered in the latter studies overlap with some of the dimensions of the brand love scale by Batra et al. (2012). Moreover, some studies that rely on the Batra et al. (2012) conceptualisation consider antecedents that partly overlap with the brand love construct. Considering that Batra et al. (2012) offer the most comprehensive conceptualisation of brand love, the small number of studies that rely on it, and even the tautology identified in some studies that rely on this approach, it is clear that explorations of the antecedents of brand love remain in their infancy. The paucity of studies following other conceptualisations also warrants the need for further work.

\subsection{Conceptual Framework}

Categorisation theory holds that individuals have a structured view of the world, with categorisation constituting a simplification strategy that is used to minimise environmental complexity (Rosch, 1978). Hence, the key function of categorisation is to differentiate objects 
in order to facilitate decision-making (Alba \& Hutchinson, 1987). Categorisation theory has been used to explain consumer behaviour (e.g., Malar et al., 2012; Stayman et al., 1992; Ülkümen et al., 2010). Malar et al. (2012) note that consumers use brand information on features to label and classify brands. In this context, they investigate how a number of attributes facilitate brand categorisation, which ultimately leads to the successful development of the intended brand personality.

Previous research (e.g., Batra et al., 2012; Fournier, 1998) has revealed that consumers love brands that are superior on one or more qualities. The information processing model and the experiential approach are two complementary views of consumer behavior (Holbrook \& Hirschman, 1982) that offer guidance to identify potential brand qualities. The former considers that consumer decision-making is based on information search and evaluation of utilitarian attributes, being associated with tangible benefits and objective features. The experiential approach "focuses on the symbolic, hedonic, and aesthetic nature of consumption" (Holbrook \& Hirschman, 1982, p. 132).

These two models reflect the view that products and, more generally, brands, deliver both functional, symbolic, and experiential benefits (e.g., Dhar \& Wertenbroch, 2000). Functional benefits address externally-determined consumption needs; symbolic benefits address needs that are internally determined, such as those involving ego-identification or self-enhancement; and experiential benefits respond to the desire for sensory pleasure, cognitive stimulation, and/or variety (Park, Jaworski, \& Maclnnis, 1986).

Both more tangible, product-related, as well as more intangible, abstract, symbolic qualities may contribute to the development of brand love. Accordingly, and similarly to Malar et al. (2012), we identify a number of brand qualities that could lead consumers to more precisely categorise a brand and, consequently, develop such brand relationships. Upon a review of the literature on product attributes used in marketing studies, we retained perceived quality and 
brand innovativeness as attributes with a higher utilitarian weight. Quality evaluations concern a product's design and manufacture (Rauschnabel \& Ahuvia, 2014), and innovativeness is also frequently assessed with regard to products' novel attributes, but may also include imagerelated issues (Kunz et al., 2011). As to the brand qualities with a higher weight of intangible, symbolic traits, we consider brand credibility, customer intimacy, brand uniqueness, and brand prestige, all of which, research has shown to contribute to relevant consumer responses. Erdem et al. (2006) refer to brand credibility as the credibility of a brand signal, and thus as a symbolic cue. Brand uniqueness addresses individuals' needs to differentiate from others (Franke \& Scheier, 2008), thereby satisfying ego-identification needs. Brand intimacy is a quality that assures consumers that the brand is committed to continuously addressing their needs, understanding and caring for them (McAlexander, Schouten, \& Koenig, 2002), which is also in the sphere of symbolic needs. As for brand prestige, it is defined as the extent to which consumers associate status or esteem with a brand (Stokburger-Sauer, Ratneshwar, \& Sen, 2012), thus being part of the symbolic realm. Finally, we consider perceived value, which concerns consumers' assessment of a brand's utility based on a comparison of what consumers get, whether functional, symbolic, or experiential, against the costs (monetary and nonmonetary) (Zeithaml, 1988).

In our model, brand uniqueness, brand prestige, and perceived value are predicted to mediate the effects of the remaining brand qualities, namely perceived quality, brand innovativeness, credibility, and intimacy. This mirrors the view that uniqueness, prestige, and perceived value are summary qualities influenced by other specific brand qualities. Perceptions of brand uniqueness rely on the extent to which a brand is unique on one or more dimensions, which may relate to both product features (e.g., quality), as well as to more intangible qualities (Carpenter et al., 1994; Malar et al., 2012). In this regard, Starbucks sought to build a unique experience around coffee consumption through high quality coffee, service (customer 
intimacy), and atmosphere. Hence, the experience possesses the summary quality of uniqueness. Prestige may be associated with a specific attribute or the characteristics of the overall offer (Dubois \& Czellar, 2002). Research indicates that prestige may arise from product quality (He et al., 2012), globalness (Steenkamp et al., 2003), and scarcity (Bearden \& Etzel, 1982) and, hence, its quality as a summary construct. Zeithaml (1988) also acknowledges the higher order dimension of prestige. Perceived value is the ultimate key mediator in the relationship between the other brand qualities and brand love. The reason for this is that it is a higher level abstraction that may include in the value equation, benefits and costs that are higher level abstractions by themselves (e.g., prestige) (Zeithaml, 1988; see also Cronin et al., 2000). Not surprisingly, the mediating role of perceived value has been considered in previous studies (e.g., Cronin et al., 2000; La et al., 2009). Following the principle that appraisal leads to emotional responses (Bagozzi, 1992), as each brand quality considered in our model involves an appraisal, each is predicted to affect brand love directly. This implies that perceived value, the highest level abstraction antecedent, only partially mediates the effects of the remaining qualities, a suggestion which is consistent with previous research (e.g., Cronin et al., 2000). Hence, past research signals a partial mediation role for perceived value, but it does not offer definite answers in this regard. Finally, we also consider three common outcomes of brand love: brand loyalty, word of mouth, and willingness to pay a premium price. The research model is presented in Figure 1. 


\subsection{Research Hypotheses}

\section{Antecedents with a higher level of abstraction: Mediating variables}

Perceived value, the highest order antecedent in the model, concerns the overall assessment consumers make of what they receive (e.g., convenience, taste, and functionality) against what they give (including monetary and non-monetary costs) (Kirmani \& Zeithaml, 1993). Perceived value has been linked with important consumer psychological and behavioural responses (e.g., La et al., 2009), and has been designated as a major strategic objective (Cronin et al., 2000). This is to be expected, since value considers benefits, which address consumers' diverse needs, whose satisfaction is the end goal of consumption, as well as the sacrifice associated with a certain benefit package, which may become too high for consumers due to their economic restrictions, making an offer unaffordable and, thus, of low value (e.g., Dodds et al., 1991). Accordingly, consumers have much to gain as the ratio of benefits to sacrifices increases. Therefore, and consistent with the appraisal $\rightarrow$ emotional response paradigm (Bagozzi, 1992), we predict the following:

H1: Perceived value is positively related to brand love.

Brand Prestige is the degree to which status or esteem is associated with a brand (Baek et al., 2010; Stokburger-Sauer et al., 2012). Tuan (1980, p. 472) argues that "our fragile sense of self needs support, and this we get by having and possessing things because, to a large degree, we are what we have and possess". The principles of self-definition (see Dutton et al., 1994), namely self-enhancement and self-distinctiveness, help to explain why brand prestige should be positively related to brand love. The development of brand relationships is influenced by what one thinks about a brand's qualities, as well as by the construed external image, i.e., what the individual believes others think of an object (see Dutton et al., 1994). Hence, the 
consumption of brands that are prestigious, i.e. admired by others, enables consumers to project themselves into the glory of the brand, thereby enhancing the vision they have of themselves (Bhattacharya \& Sen, 2003), and simultaneously satisfying their need for self-enhancement. In addition, as prestige is a scarce resource, it should also contribute towards addressing one's need for self-distinctiveness. Therefore, brand prestige is likely to have a significant role in explaining the development of love towards brands. It has also been argued that brand prestige is positively related to customer value (Steenkamp et al., 2003; see also Zeithaml, 1988). Thus, we hypothesise

H2a: Brand prestige is positively related to perceived value.

H2b: Brand prestige is positively related to brand love.

Brand uniqueness is "the degree to which customers feel the brand is different from competing brands" (Netemeyer et al., 2004, p. 211). Since love constitutes an experience that is extreme (Ahuvia et al., 2009), the brands that are loved must stand apart from competition, and this makes brand uniqueness a relevant explanatory variable. Humans, by nature, often need to feel different from others in their efforts to feel good about themselves (Golder et al., 2012), which they must do to build their self-confidence (Stokburger-Sauer et al., 2012). This view fits with social identity theory, which claims that individuals need to simultaneously be similar to, as well as to be different from, others (Brewer, 1991). Accordingly, unique brands contribute to the need for individuals to differentiate from others. Moreover, and according to choice theory (Dhar \& Sherman, 1996), attributes that are common to competing brands do not affect choice probabilities, as they provide little diagnostic inputs for the development of preferences. In this context, relying on the unique features to make decisions among alternative brands provides a simple heuristic for decision tasks (Netemeyer et al., 2004). Research has found that perceived 
uniqueness drives customer utility (e.g., Franke \& Schreier, 2008), and that unique attributes and higher prices drive consumer preferences and, hence, competitive advantage (e.g., Carpenter et al., 1994). Accordingly, brand uniqueness should be positively related to perceived value and brand love. In fact, consumers in qualitative studies, referred to their favourite brand as being different and unique, which may be related to the feeling of idealisation addressed in theories of interpersonal love (Albert et al., 2008). Finally, as prestige involves some rare, unique properties (e.g., Dubois \& Czellar, 2002; Park et al., 1991), brand uniqueness should contribute towards a brand's prestige. In summary, we predict the following:

H3a: Brand uniqueness is positively related to brand prestige.

H3b: Brand uniqueness is positively related to perceived value.

H3c: Brand uniqueness is positively related to brand love.

\section{Antecedents with a lower level of abstraction: Exogenous variables}

\section{$\underline{\text { Functional qualities }}$}

Perceived quality, the perception of a product's degree of excellence, is formed from consumers' impressions regarding intrinsic (e.g., physical characteristics such as ingredients and functionality) as well as extrinsic cues (e.g., the package) (Brucks et al., 2000; Erdem \& Swait, 1998; Zeithaml, 1988). Thus, perceived quality is at a higher level of abstraction when compared to specific cues. The importance of perceived quality in consumer behaviour has been established, with research positioning perceived quality as key for brand equity (e.g., Netemeyer et al., 2004) and satisfaction (e.g., Chan et al., 2010). This is not unexpected, given that quality is associated with great performance or excellence in meeting customer needs, and this provides a good reason for consumers to love brands. Not surprisingly, previous research has demonstrated the contribution of quality to brand love (Batra et al., 2012; Rauschnabel \& 
Ahuvia, 2014). Since unique know-how concerning a specific attribute or the overall quality of an offer is key for prestigious judgements (Dubois \& Czellar, 2002, Bhattacharya \& Sen, 2003), perceived quality, being associated with feelings of excellence, contributes towards the building of consumers' perceptions of brand prestige (e.g., Vigneron and Johnson, 1999). In addition, because developing brands that are perceived to have a superior quality, that is, are considered the best of their class in terms of performance on a single or on a number of attributes, are feasible only for a small number of firms, it is expected that consumers should consider such brands as unique. Finally, perceived quality should also be positively related to perceived value, since the latter is a more abstract construct that considers both functional as well as symbolic benefits (e.g., Zeithaml, 1988). Accordingly, we predict the following:

H4a: Perceived quality is positively related to brand uniqueness.

H4b: Perceived quality is positively related to brand prestige.

H4c: Perceived quality is positively related to perceived value.

H4d: Perceived quality is positively related to brand love.

Brand innovativeness: Brands may be perceived as innovative as a result of a systematic approach to the generation of creative solutions to market opportunities, and this may include introducing in the market new designs, product attributes, and marketing approaches (Kunz et al., 2011; see also La et al., 2009). The well documented positive link between innovation and organisational performance (e.g., Han et al., 1998) demonstrates that innovation affects consumers in positive ways for organisations. Innovation contributes to the introduction of market offers that more closely satisfy customers' changing needs (e.g., Subramaniam \& Youndt, 2005). Moreover, innovators, being the first to introduce new offerings to the market, contribute to the shaping of consumers' learning, preferences, and behaviour, thereby 
providing themselves with an advantage over late entrants (Carpenter \& Nakamoto, 1989). Furthermore, a brand's innovative approaches may deliver new experiences, resulting in consumer excitement (e.g., Haberland \& Dacin, 1992). An iconic case is Apple, which has created a number of offers that resulted in a horde of fans. Thus, brand innovativeness appears to have a potential influence over brand love. In addition, innovativeness leads to the differentiation of a brand, i.e., the extent to which it stands out against competing offers and, hence, to the perception of its uniqueness (Fang, 2008). Moreover, as innovativeness is associated with an enduring capability (e.g., Kunz et al., 2011), a unique know-how, it should be positively related to perceptions of brand prestige (see Dubois \& Czellar, 2002), along with perceived value. Hence, we predict the following:

H5a: Brand innovativeness is positively related to brand uniqueness.

H5b: Brand innovativeness is positively related to brand prestige.

H5c: Brand innovativeness is positively related to perceived value.

H5d: Brand innovativeness is positively related to brand love.

\section{Symbolic qualities}

Brand credibility, which concerns consumers' judgements about the believability of the information held by a brand, implies that consumers perceive the brand to have the ability and willingness to deliver its promises in a systematic way (Erdem et al., 2006). In the presence of imperfect and asymmetrical information, consumers frequently rely on brand signals to make inferences about the qualities of a specific offer (Wernerfelt, 1988). In particular, brands act as meaning repositories, which are built across time as a function of a firm's marketing mix consistency and investments in the brand (Erdem \& Swait, 1998). Accordingly, taking the brand as a signal enables consumers to develop confidence about that brand's attributes, 
thereby lowering perceived risk and information costs (Erdem \& Swait, 1998). The role of brand credibility in consumers' decision-making is well established. Swait and Erdem (2007), for example, determined that brand credibility affects brand choice, and Baek et al. (2010, p. 663) state that it "provides unbeatable benefits to both consumers and companies". Such an assessment should thus be important for the development of brand love. Moreover, in a market with asymmetrical information, credibility is considered one of the most important characteristics of a brand signal, as it affects the effectiveness of the information conveyed to buyers (cf. Erdem \& Swait, 1998). Hence, those brands that are perceived by consumers as more truthful and dependable should be judged as more unique. Erdem et al. (2006) also note that credibility hinges on firms' investments in their brands, and on a firm's abilities to deliver its promises, which depends on marketing, technological and other skills and resources (see Erdem \& Swait, 2004). This also suggests that credibility should result from a unique bundle of know-how, contributing to perceptions of brand uniqueness and prestige. Finally, assessments of perceived value should benefit from credibility, by reassuring consumers about benefits and by reducing costs, namely informational ones (e.g., Hauser \& Wernerfelt, 1990). Therefore, we predict the following:

H6a: Brand credibility is positively related to brand uniqueness.

H6b: Brand credibility is positively related to brand prestige.

H6c: Brand credibility is positively related to perceived value.

H6d: Brand credibility is positively related to brand love.

Brand intimacy, the perception customers have of the extent to which the brand is concerned with them and is committed to understanding and serving their needs, requires communication so that a brand may truly understand the needs and preferences of customers (see Akçura \& 
Srinivasan, 2005; Yim et al., 2008). Such a focus involves putting customers' interests first, thus signalling a total customer satisfaction focus (e.g., Deshpande \& Farley, 1993; Han et al., 1998). This mirrors the role of intimacy in interpersonal love (Sternberg, 1986), which involves, amongst other feelings, the desire to enhance the well-being of the loved one, an intimate communication with the loved one, and having a high regard for the loved one. In a brand context, this requires intense boundary spanning activity, so that a deep understanding of customers' current and latent needs is developed (e.g., Kohli \& Jaworski, 1990). Deshpande and Farley (1993) determined that a firm's business performance was positively related to customers' assessments of the firm's customer orientation. Moreover, customer intimacy arising from communications leading to a true understanding of customers' needs and preferences, enables firms to cross-sell products that more closely fit customers' needs, thereby increasing customer loyalty (Akçura \& Srinivasan, 2005). Consequently, perceptions that a brand is engaged in developing a true understanding of customers' needs, and cares for their satisfaction, appears to be an important brand quality (McAlexander et al., 2002). Not surprisingly, brand intimacy has been considered a mantra of today's marketing (Bhattacharya $\&$ Sen, 2003). Consequently, intimacy appears to be an important factor for triggering a brand love relationship. Moreover, building intimacy rests on accumulating knowledge (e.g., Ahuvia, 2005), bringing “warmth" to a relationship (Sternberg, 1986), but this requires continuous work from firms (Yim et al., 2008). As customer intimacy relies on a firm's ability "to truly understand its customers' needs and preferences" (Akçura and Srinivasan, 2005, 1007), its development rests on a number of internal capabilities, such as those involved in linking the organisation with its external environment, enabling it to anticipate market needs and develop lasting relationships with customers, therefore underlining the development of positional advantages (e.g., Day, 1994). Thus, as perceptions of intimacy grow, the more consumers should perceive a brand to be unique. Moreover, by relying on distinctive capabilities and by 
conveying a particular concern for the customer, the brand intimacy quality should contribute to feelings of admiration, therefore resulting in perceptions of brand prestige. Finally, the symbolic benefits it delivers to customers should be positively related to perceived value. Accordingly, we predict the following:

H7a: Brand intimacy is positively related to brand uniqueness.

H7b: Brand intimacy is positively related to brand prestige.

H7c: Brand intimacy is positively related to perceived value.

H7d: Brand intimacy is positively related to brand love.

\section{Brand Love Outcomes}

We aim to replicate the findings obtained in other studies indicating that brand love results in brand loyalty, positive word of mouth, and willingness to pay a price premium (e.g., Albert \& Merunka, 2013; Batra et al., 2012). Brand Loyalty is "a deeply held commitment to rebuy or repatronise a preferred product/service consistently in the future, thereby causing repetitive same-brand or same brand-set purchasing, despite situational influences and marketing efforts having the potential to cause switching behaviour" (Oliver, 1997, p. 392). Positive word-ofmouth concerns the extent to which consumers talk positively about a brand to others (Carroll \& Ahuvia, 2006). Finally, willingness to pay a price premium is the money a consumer is willing to pay for his/her favourite brand over what he/she would pay for a comparable/lesser brand (Netemeyer et al., 2004). Loving a brand is an extremely gratifying experience (Ahuvia et al., 2009). Accordingly, such brand involvement should encourage consumers to strive for relationship maintenance, as well as to talk to others about the loved brand, thereby enhancing their social and inner self (e.g., Carroll \& Ahuvia, 2006). Hence, we offer the following: 
H8a: Brand love is positively related to positive brand loyalty.

H8b: Brand love is positively related to positive word of mouth.

H8c: Brand love is positively related to the willingness to pay a price premium.

\section{Method}

\subsection{Data Collection}

In our study we use two samples. The first is composed of students from a major university in the centre of Portugal. We distributed 2,000 questionnaires to students across the campus and placed a number of closed ballot boxes across it to collect the questionnaires and reassure students about the anonymity of their responses. After eliminating those questionnaires with excessive missing responses, we retained 534 for analysis, yielding a net response rate of $26.7 \%$. As for the respondents, $51.1 \%$ were men, the average age being 24 years, and $82.3 \%$ of whom were full time students. The second sample is composed of adults who were selected under a snowball method, which has been used frequently to investigate the relationship between brands and consumers (e.g., Albert et al., 2008; Valta, 2013). We distributed 800 questionnaires through 60 (sixty) acquaintances located in different places across the country, with each being responsible for collecting the questionnaires completed by others they knew. After eliminating those questionnaires with excessive missing responses, we retained 484 for analysis, giving a net response rate of $60.5 \%$. As to the respondents, $41.8 \%$ were men, the average age being 33 years, $58.8 \%$ of the sample were in work, and $27.6 \%$ full or part-time students.

\subsection{Measurement}

Initially, the questionnaire asked respondents to think of, and write, the name of a brand they had bought and were using, and with which they felt they had a special and strong relationship, 
an approach followed by others also researching in a branding context (e.g., Alexandrov et al., 2013; Choi \& Winterich, 2013; Tuskej et al., 2013; Albert \& Merunka, 2013). Subsequently, the pre-tested questionnaire relied on previously-validated measures, and used a seven-point Likert scale. Brand uniqueness and perceived value are from Netemeyer et al. (2004), brand innovativeness is from Fang (2008), perceived quality is from Lam et al. (2013), brand prestige is from Stokburger-Sauer et al. (2012), brand credibility is from Erdem et al. (2006) and Baek et al. (2010), customer intimacy is from Breivik and Thorbjørnsen (2008), and brand love, a 26-item scale, is from Batra et al. (2012) and Bagozzi, Batra, \& Ahuvia (2016). Concerning the consequences, brand loyalty is from Algesheimer et al. (2005) and Batra et al. (2012), word-of-mouth is from Maxham III and Netemeyer (2002), and willingness to pay a price premium is from Netemeyer et al. (2004).

All measures were subjected to confirmatory factor analysis. Data analysis relied on AMOS 21. In the process of fitting the CFA model for sample 1, we determined a negative residual variance for 'positive emotional connection'. As this variance was only significant at $p=0.071$, we fixed it to a small positive value. For sample 2, we determined a highly significant negative residual variance for the brand love component 'intuitive fit' (comprising two items) which, for this reason, was eliminated from the analysis.

After model purification, we obtained an acceptable fit (sample 1: $\chi 2=3858.61, \mathrm{df}=1526$;

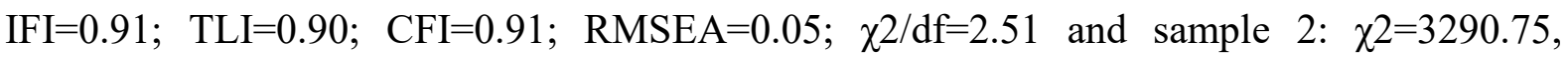
$\mathrm{df}=1362 ; \mathrm{IFI}=0.92 ; \mathrm{TLI}=0.91 ; \mathrm{CFI}=0.92 ; \mathrm{RMSEA}=0.05 ; \chi 2 / \mathrm{df}=2.42)$. We obtained evidence of convergent validity as all items loaded on the appropriate factors, with the loadings being highly significant (Table 1). Moreover, the composite reliability exceeds in all cases the recommended 0.70 threshold level. As to the average variance extracted, all values exceed the 0.60 mark. Moreover, we obtained evidence of discriminant validity as the squared correlation between each pair of constructs is lower than the corresponding average variances extracted 
(Fornell \& Larker, 1981), the exception being brand loyalty and brand love in sample 2, which correlate at 0.828. Following Anderson and Gerbing (1988), we conducted a chi-square difference test in which we compared a model with the correlation between the constructs constrained to 1.0 , to an unconstrained model. The results indicate that the latter fits significantly better, and this is evidence of discriminant validity (Anderson \& Gerbing, 1988). Hence, the measurement models show acceptable levels of reliability and validity. Table 2 provides univariate statistics, correlation coefficients, Cronbach alphas, average variances extracted, and composite reliabilities.

Insert Table 1 about here

$* * * * * * * * * * * * * * * * * * * * * * * * * * * * *$

$* * * * * * * * * * * * * * * * * * * * * * * * * * * * *$

Insert Table 2 about here

Finally, and in line with Podsakoff et al. (2003), we took procedural remedies in order to minimise the possibility of common method variance. More specifically, we did not inform respondents about the purpose of the study, and ensured them that their responses would be anonymous and confidential, and this should have contributed to reduce response bias. Respondents were also informed that there were no right or wrong answers, and that their participation was extremely important for the success of the research, and this should have contributed to the quality of the data. We have also sought to reduce item ambiguity by avoiding unusual and ambiguous words, and the two pre-tests carried out contributed to this. 
The reliance on previously-validated scales should have also helped in this process. In addition, we conducted some statistical analysis to assess the extent to which method variance could be affecting the results. In particular, we followed the Chaudhuri and Ligas (2009) procedure, which compares simpler with more complex CFA models. Accordingly, if common method variance exists, then a more complex model (more factors) should not fit better than a simpler CFA model. In this process, we ran a number of CFA models and conducted chi-square difference tests, which indicated that the best fit was obtained when all the factors considered in our model (the largest, more complex CFA model) were specified. This suggests that method variance should not exert a substantial impact on estimations. Moreover, we relied on the marker variable technique (Lindell \& Whitney, 2001) to further assess the influence of method variance. For this purpose, we included in the questionnaire a three-item marker variable - the extent to which consumers find it easy to shop on the internet (Childers et al., 2001). Following Lindell and Whitney (2001), we adjusted the correlations between each independent variable and the dependent variable using the lowest correlation between the marker variable and the remaining variables, which serves as an indicator of common method bias. The obtained adjusted correlations are still significant, and this is evidence that common method variance is not a matter of great concern.

\section{Results}

The fit of the structural model is within current standards (sample 1: $\chi^{2}=3663.80, \mathrm{df}=1474$; $\mathrm{IFI}=0.91 ; \mathrm{TLI}=0.90 ; \mathrm{CFI}=0.91 ; \mathrm{RMSEA}=0.06 ; \chi^{2} / \mathrm{df}=2.49$ and sample $2: \chi^{2}=4321.42, \mathrm{df}=1644$; $\left.\mathrm{IFI}=0.90 ; \mathrm{TLI}=0.89 ; \mathrm{CFI}=0.90 ; \mathrm{RMSEA}=0.06 ; \chi^{2} / \mathrm{df}=2.63\right)$. In these estimations we control for age and gender. Given the length of the table showing the results of model estimation, in the interests of parsimony we omit from it, the paths from the controls to all the dependent 
variables in the model. Most of the proposed hypotheses are supported by the results (see Table 3 and Figure 2). Moreover, and as an additional check on common method variance, we ran a further structural model in which the marker variable was an antecedent of each dependent latent variable. The results indicated that the fit of the predicted model was better. Furthermore, the inclusion of the marker variable induced no relevant changes in the statistical significance of the remaining paths. This is reassuring in respect of the robustness of the results, confirming that common method variance is not interfering with the results.

Insert Table $3 \& 4$ and Figure 2 about here

Table 4 presents the indirect (and total) effects and their significance, which are instrumental in determining whether partial, full, or no mediation at all is at work. In testing the mediating effects, we followed the approach suggested by Zhao et al. (2010), who argue that the only requirement for mediation is the significance of the indirect effect, which should be tested through bootstrapping. The indirect effects are considered in the discussion. We now present the results of the hypotheses testing, which relies on one-tail tests. These results concern the direct relationships we predicted.

We start with the findings concerning the constructs with a higher level of abstraction. Perceived value is positively related to brand love, and this is observed in both samples, thus supporting $\mathrm{H} 1(\mathrm{~b} 1=0.38, \mathrm{p}<0.01 ; \mathrm{b} 2=0.52, \mathrm{p}<0.01)$. Brand prestige only contributes directly to perceived value in sample 1 (students), but this relationship is negative. This contradicts $\mathrm{H} 2 \mathrm{a}$ ( $b 1=-0.12, p<0.05 ; b 2=0.09, p>0.05)$. H2b predicted that brand prestige was positively related to brand love. We obtained positive and statistically significant coefficients in both samples and, thus, H2b is supported ( $\mathrm{b} 1=0.14, \mathrm{p}<0.05 ; \mathrm{b} 2=0.12, \mathrm{p}<0.05$ ). 
Brand uniqueness was predicted to be directly and positively related to brand prestige, perceived value and brand love. The results support these predictions since the obtained coefficients are significant and positive for prestige $(\mathrm{H} 3 \mathrm{a})(\mathrm{b} 1=-0.06, \mathrm{p}>0.05 ; \mathrm{b} 2=0.22, \mathrm{p}<0.01)$, though only in sample 2 , perceived value $(\mathrm{H} 3 \mathrm{~b})(\mathrm{b} 1=0.23, \mathrm{p}<0.01 ; \mathrm{b} 2=0.15, \mathrm{p}<0.01)$, and brand love $(H 3 c)(b 1=0.11, p<0.05 ; b 2=0.14, p<0.01)$.

Subsequently, we consider the constructs with a lower level of abstraction. Perceived quality performs mostly as expected, relating positively to uniqueness ( $\mathrm{H} 4 \mathrm{a})$ (b1=0.39, $\mathrm{p}<0.01$; $\mathrm{b} 2=0.46, \mathrm{p}<0.01)$, prestige $(\mathrm{H} 4 \mathrm{~b})(\mathrm{b} 1=0.53, \mathrm{p}<0.01 ; \mathrm{b} 2=0.40, \mathrm{p}<0.01)$, and perceived value $(\mathrm{H} 4 \mathrm{c})$ ( $\mathrm{b} 1=0.19, \mathrm{p}<0.05 ; \mathrm{b} 2=0.18, \mathrm{p}<0.01)$. Unexpectedly, however, quality does not relate directly to brand love in either sample ( $\mathrm{b} 1=0.03, \mathrm{p}>0.05 ; \mathrm{b} 2=0.02, \mathrm{p}>0.05$ ). This finding contradicts previous evidence and fails to support $\mathrm{H} 4 \mathrm{~d}$. As to brand innovativeness, the results are less clear-cut. Innovativeness related positively to brand uniqueness in both samples $(\mathrm{b} 1=0.44$, $\mathrm{p}<0.01 ; \mathrm{b} 2=0.28, \mathrm{p}<0.01$ ), thus supporting H5a. It also relates positively to brand prestige, but only in sample $2(\mathrm{~b} 1=0.07, \mathrm{p}>0.05 ; \mathrm{b} 2=0.10, \mathrm{p}<0.05)$, thus partially supporting H5b. Against predictions, brand innovativeness does not relate directly in a significant way with perceived value $(\mathrm{b} 1=-0.07, \mathrm{p}>0.05 ; \mathrm{b} 2=0.05, \mathrm{p}>0.05)$, thus rejecting $\mathrm{H} 5 \mathrm{c}$, and with brand love $(\mathrm{b} 1=0.04$, $\mathrm{p}>0.05 ; \mathrm{b} 2=0.04, \mathrm{p}>0.05$ ), implying that H5d is also not supported.

Credibility is positively related to brand prestige ( $\mathrm{b} 1=0.33, \mathrm{p}<0.01 ; \mathrm{b} 2=0.26, \mathrm{p}<0.01$ ) and perceived value $(\mathrm{b} 1=0.34, \mathrm{p}<0.01 ; \mathrm{b} 2=0.29, \mathrm{p}<0.01)$ in both samples, thus supporting H6b and H6c, respectively. We found some differences in the relationship between brand credibility and brand uniqueness, since it is supported in sample 1 but not in sample 2 (H6a) (b1=0.11, p<0.05; $\mathrm{b} 2=0.05, \mathrm{p}>0.05)$. The same pattern was observed between brand credibility and brand love (H6d) $(\mathrm{b} 1=0.14, \mathrm{p}<0.01 ; \mathrm{b} 2=0.03, \mathrm{p}>0.05)$.

We predicted intimacy to be directly and positively related to brand uniqueness, brand prestige, perceived value, and brand love. However, the results only support the direct relationship with 
brand love $(\mathrm{H} 7 \mathrm{~d})(\mathrm{b} 1=0.25, \mathrm{p}<0.01 ; \mathrm{b} 2=0.18, \mathrm{p}<0.01)$, and with perceived value in sample 1 $(\mathrm{H} 7 \mathrm{c})(\mathrm{b} 1=0.10, \mathrm{p}<0.05 ; \mathrm{b} 2=0.04, \mathrm{p}>0.05)$. Accordingly, $\mathrm{H} 7 \mathrm{a}$ (uniqueness) $(\mathrm{b} 1=0.02, \mathrm{p}>0.05$; $\mathrm{b} 2=0.04, \mathrm{p}>0.05)$, and $\mathrm{H} 7 \mathrm{~b}$ (prestige) $(\mathrm{b} 1=-0.01, \mathrm{p}>0.05 ; \mathrm{b} 2=-0.01, \mathrm{p}>0.05)$ are rejected. Finally, the outcomes of brand love are completely in line with predictions. In both samples, brand love relates positively with brand loyalty (H8a) $(\mathrm{b} 1=0.80, \mathrm{p}<0.01 ; \mathrm{b} 2=0.88, \mathrm{p}<0.01)$, word-of-mouth (H8b) (b1=0.69, $\mathrm{p}<0.01 ; \mathrm{b} 2=0.75, \mathrm{p}<0.01$ ), and willingness to pay a price premium (H8c) (b1 $=0.71, \mathrm{p}<0.01 ; \mathrm{b} 2=0.74, \mathrm{p}<0.01$ ). These results reinforce the universality of brand love outcomes.

\section{Discussion}

The brand love construct has been recently proposed as a means of capturing the nature of the relationship between customers and brands (e.g., Batra et al., 2012). Preliminary evidence indicates that brand love might have important consumer implications, including brand loyalty and positive word-of-mouth. However, the antecedents of brand love remain largely unknown. Accordingly, the purpose of this study was to enlighten such drivers, knowledge that is extremely relevant for targeting managerial action. In this process, we developed a model comprising previously-untested relationships. The results we obtained clearly support most predictions of the research model, and have important academic and practical implications.

\section{Antecedents with a higher level of abstraction}

Our model contained variables with different levels of abstraction. At the higher level we had brand uniqueness, brand prestige, and perceived value. All of these constructs contributed directly to brand love. Brand love is a special consumption relationship (Ahuvia et al., 2009) and, thus, involves unique qualities (Batra et al., 2012). Hence, our results underscore the valuable symbolic and emotional meanings evoked by uniqueness and prestige in developing 
a special relationship between brands and customers. As to perceived value, the highest order antecedent in the model, the results support its important mediating role observed in past studies (e.g., Cronin et al., 2000; La et al., 2009).

Brand uniqueness is associated in a positive way with prestige and perceived value in both samples, the exception being the non-significant relationship with prestige in sample 1. Feeling that a brand is different from others both in terms of functional and/or symbolic aspects, seems to enhance the bundle of benefits perceived, and appears to drive consumers to consider the brand as prestigious, which is important for one's self-enhancement and self-distinctiveness (see Dutton et al., 1994). The non-significant finding in sample 1 is possibly the result of the youth of this sample and of lower incomes, which prohibits access to more expensive, prestigious brands. This might lead them to appreciate uniqueness for reasons other than the wealth and status the former could signal. In addition, brand uniqueness also had significant indirect effects on brand love. Hence, its effects on brand love are partially mediated.

The relationship between brand prestige and perceived value did not conform to our expectations. The relationship was not significant for sample 2 (general population) and negative for sample 1 (student sample). An explanation for these findings is that prestige, being associated with feelings of admiration, exclusivity, and wealth (e.g., Alden et al., 1999; Baek et al., 2010), may not fit well with the low price component of perceived value (Steenkamp et al., 2003). It has also been noted that perceived value may have a more functional nature (Netemeyer et al., 2004), whereas prestige is more symbolic-oriented. Finally, Rauschnabel et al. (2016) find prestige and brand love inversely related (they also find that prestige is inversely related to word-of-mouth). They note that the nature of their study and the setting, the brand personality of universities, may help explain the findings. For example, it is possible that the higher prices of leading universities create financial difficulties for students, which may 
adversely affect brand love. Overall, the results concerning the more abstract constructs offer an important novel contribution.

\section{Antecedents with a lower level of abstraction}

Perceived quality relates positively to uniqueness, prestige, and perceived value. Quality, though involving functional attributes, also evokes symbolic and emotional benefits and, therefore, the positive relationship with those variables. Unlike in previous studies (e.g., Batra

et al., 2012; Rauschnabel \& Ahuvia, 2014), quality did not relate directly to brand love in both of our samples. However, the indirect effect of quality on brand love is statistically significant. Hence, quality is important for brand love. Previous studies did not include perceived value, prestige or uniqueness, alongside perceived quality, as antecedents for BL. Our findings thus help to clarify past findings, suggesting that the relationship between perceived quality and BL is totally mediated. Quality may be an attribute that is too rational when we are exploring the brand love formation, particularly in the presence of variables with a more symbolic nature, which ultimately mediate the effects of the former. This result is in line with Rauschnabel and Ahuvia (2014), who determined that brand quality had a weaker relationship with brand love when compared to anthropomorphism, a symbolic quality. Interestingly, perceived quality has a stronger relationship with prestige and uniqueness than with perceived value. This might result from perceived quality comprising a composite assessment of an offer, implying that quality is one consideration amongst many others that enter into the overall assessment.

A similar pattern of results is observed for brand innovativeness, which is only indirectly related to brand love, though only in sample 2. It is also directly and positively related to uniqueness in both samples, with prestige in sample 2, and unrelated with perceived value in both samples. Again, the functional nature of innovativeness might have led to its effect on brand love to be completely mediated by constructs with a more symbolic/emotional nature. 
As to the non-significant direct effect on perceived value, a possible explanation is related with the profusion of products with innovative features, the value of which might not always be apparent for consumers. Finally, in the student sample (sample 1), brand innovativeness did not directly relate with prestige. Again, it is possible that, due to their lower income, innovativeness might be important to students for reasons other than prestige (e.g., Alden et al., 1999). In summary, functional qualities are important in generating brand love, but seem to play an explanatory role through mediating variables with a higher symbolic content and a higher abstract level.

As to brand credibility, the results tend to conform to predictions, although differences emerged between samples. We observed that credibility is positively related to brand prestige and perceived value in both samples, and with brand uniqueness and brand love in sample 1 . These results underscore the role of credibility in shaping very close relationships with customers, and is in line with past results linking credibility to brand choice (e.g. Swait and Erdem, 2007). One possible explanation for the non-significant paths relating credibility with brand uniqueness and brand love in sample 2 is related to its demographic characteristics. Older consumers (sample 2) have been buying and consuming products for longer than students. This longer experience put them in contact with brands that were credible but that at some point in time had 'an accident', which resulted in jeopardising their image. Hence, as perceptions of brand credibility are established over time, it is possible that more mature consumers exercise greater care when considering the effects of credibility. Finally, we note that brand credibility also has significant indirect effects on brand love in both samples. Together, the direct and indirect influences place credibility as a relevant predictor of brand love.

Finally, intimacy relates positively to brand love in both samples, and with perceived value in sample 1 . The relationships predicted between brand intimacy and brand uniqueness and brand prestige were not supported. Brand intimacy involves customers' perception that the brand is 
truly concerned with their needs, and that it really strives to fulfil them (e.g., Breivik and Thorbjørnsen, 2008). This perception likely brings valuable emotional and symbolic benefits to customers, contributing to the development of a love relationship. A possible explanation for the unexpected findings might be due to the high emotional content of brand intimacy. Intimacy involves a solid bond and a great deal of complicity between customers and brands, and this may imply that intimacy has a much higher emotional content than brand uniqueness, prestige and perceived value, and this may have eroded a possible relationship with such brand qualities.

\section{Outcomes of brand love}

As to the outcomes of brand love, the results across samples are consistent with predictions. Hence, brand love is positively related with brand loyalty, word-of-mouth, and willingness to pay a premium price. A consumer loves a brand when the latter occupies a special place in his/her mind and life (Ahuvia et al., 2009). Such a unique and valuable relationship appears to lead customers to strive for its preservation, even if this implies paying a higher price for the brand. It also fosters consumers' willingness to spread positive word-of-mouth, and to reject competing brands. Hence, the relationship between customers and brands becomes stronger and lasting when brand love is present, leading to the brand's success.

In summary, the results of this investigation uncovered a novel set of variables, namely brand innovativeness, brand credibility, brand intimacy, brand prestige, brand uniqueness, and perceived value, as direct and/or indirect antecedents of brand love, which characterises a unique and quite special relationship consumers hold with a brand. The findings indicate that both functional as well as more emotional or symbolic elements are important to the formation of brand love. Moreover, the results concerning brand quality and brand innovativeness suggest that rational attributes are important for brand love, but that their effects are mediated by more 
abstract, symbolic constructs. These results also lend support to a hierarchy of effects that future research should further address. In particular, research should look at constructs with a higher level of abstraction as potential mediators of constructs with a lower abstraction level. As to the outcomes of brand love, the fact that we replicated previous findings is reassuring about their universality. Hence, these outcomes show that brand love is a matter for companies with a long-term vision aiming to strengthen the relationship between customers and their brands. Finally, two different samples were used and it is important to highlight that although the results are not completely uniform across them, they do show great consistency, and this is welcome confirmation.

\section{Practical Implications}

Our investigation provides managers with some insights concerning how to spur brand love. The results reinforce the universality of the consequences of brand love, reassuring managers that pursuing the development of brand love is warranted across countries. In this regard, the results indicate that brand managers should consider, apart from improving the quality of their brands, bringing unexpected offerings to market, i.e., innovative products and services that deliver new brand experiences. Moreover, it is important that managers carefully craft their promises to customers, so that they are able to honour them in a systematic way, thus reinforcing their brands' credibility. Another area of concern is the development of an intimate relationship with customers, which firms can accomplish by developing a deep understanding of customer needs and striving to fulfil these. Establishing diverse channels of communication, including the usage of different market research techniques, as well as putting customers' interests first, should help in that process.

Brand love concerns a unique consumption experience (Ahuvia et al., 2009). Accordingly, it appears difficult to deliver such if the brand is considered trivial. In this context, the results 
show that managers should also aim at building a brand that is unique, and this can rest on both functional and symbolic attributes. Enhancing perceptions of prestige also appears to contribute to brand love, perhaps because it satisfies consumers' needs for self-enhancement and distinction. Managers can act on this in a number of ways, namely by carefully managing the price, distribution, product features, and brand communication. Finally, firms can also promote brand love by enhancing consumers' perceptions of the brand's value. This can be accomplished by improving the ratio of the benefits, both functional and symbolic, to that of the perceived costs of the offer, whether monetary, psychological or other. Ikea appears to be a brand with which people have a special relationship (Roberts, 2005). Yoon (2015) summarises key issues behind Ikea's success, and which underlie our findings. Ikea pays attention to tangible attributes such as price, but also to products' form, quality, and function. Moreover, the company relies on innovation to design quality furniture, but also applies it to marketing efforts. This effort is matched with anthropological research, involving regular visits to consumers' homes, as well as the use of other communication instruments, in order to gain a good, intimate understanding of customer needs. Moreover, Ikea employs prestigious designers to bring something exciting and new to the brand. In summary, brand managers can spur brand love by taking action in several areas. This is an important observation, since different firms possess different bundles of skills and resources, which should delimit the most effective areas for managerial intervention.

\section{Limitations and Directions for Future Research}

We relied on a single informant to collect the data on the dependent and independent variables, and this raises the issue of common method variance. Notwithstanding, the procedural remedies we applied should have mitigated this problem. Moreover, the statistical analysis we conducted suggests that common method variance might not have affected the results in a 
substantial manner. The study also has a cross-sectional nature, but a longitudinal approach would be advantageous. Specifically, such a study would enable the collection of data on the potential consequences of brand love on subsequent occasions, and this would provide information on the dynamic effects of brand love, i.e., its short, medium, and long-term effects. It would be interesting to determine how brand love relates to future purchase frequency, consumption levels, purchase of competing brands, and response to competing sales promotions. Moreover, the samples used in this research, although in line with other studies (e.g., Alexandrov et al., 2013; Brakus et al., 2009; Erdem et al., 2006), have a convenient nature, and future studies could improve in this regard. It is also possible that the frequency with which consumers use a brand, as well as how long they have been using it, affect the love for it. This issue was not controlled in the current study and has also been neglected in past research, and should thus be addressed in future endeavours. Moreover, respondents were free to indicate the referent brand. Although in line with past branding research, this approach, despite contributing to the generalisation of results, may also have caused some bias, as the determinants of brand love may differ across product types. In addition, having respondents assessing researcher selected brands should increase the variance of measures, contributing to stronger relationships. Additionally, such approach should minimise individuals' bias in brand selection.

Another direction for future research is related to moderating effects. It is possible that the effects of brand love (as well as of its antecedents) might be moderated by personal as well as contextual variables. Self-esteem, regulatory focus, brand schematicity, and product involvement are examples of the former. Contextual variables that could be considered as moderators include type of product, the stage of market development, and the number of competing brands in the market. Moreover, the results we obtained revealed some differences across the two samples, which have quite different characteristics. This reinforces the need for 
future research to investigate whether consumers with different socio-demographic characteristics hold the same view of brand love, as well as of its antecedents and consequences. Moreover, the number of antecedent variables that have been related to brand love is still scarce. Hence, future studies might address this. Finally, it would be quite valuable to link brand love measures with brand financial performance. This would enable firms to calibrate their brand relational investments. 


\section{References}

Alden, D. L., Steenkamp, J.-B. E. M., \& Batra, R. (1999). Brand Positioning Through Advertising in Asia, North America, and Europe: The Role of Global Consumer Culture. Jounal of Marketing, 63, 75-87.

Alexandrov, A., Lilly, B., \& Babakus, E. (2013). The effects of social- and self-motives on the intentions to share positive and negative word of mouth. Journal of Academy of Marketing Science, 41(1), 531-546.

Algesheimer, R., Dholakia, U. M., \& Herrmann, A. (2005). The Social Influence of Brand Community : Evidence from European Car Clubs. Journal of Marketing, 69(July), 1934.

Ahuvia, Aaron (1992) ,"For the Love of Money: Materialism and Product Love", in SV Meaning, Measure, and Morality of Materialism, eds. Floyd W. Rudmin and Marsha Richins, Provo, UT : Association for Consumer Research, Pages: 188-198.

Ahuvia, Aaron (2005), "Beyond the Extended Self: Loved Objects and Consumers' Identity Narratives," Journal of Consumer Research, 32 (1), 171-184.

Ahuvia, A. C., Batra, R., \& Bagozzi, R. P. (2009). Love, desire and identity: a conditional integration theory of the love of things. The Handbook of Brand Relationships. New York: ME Sharpe, 342-357.

Akçura, M. T., \& Srinivasan, K. (2005). Research note: Customer intimacy and cross-selling strategy. Management Science, 51(6), 1007-1012.

Alba, J. W., \& Hutchinson, J. (1987). Dimensions of consumer expertise. Journal of Consumer Research, 13(4), 411-454.

Albert, N., Merunka, D., \& Valette-Florence, P. (2008). When consumers love their brands: Exploring the concept and its dimensions. Journal of Business Research, 61(10), 10621075.

Albert, N., Merunka, D., \& Valette-Florence, P. (2013). Brand passion: Antecedents and consequences. Journal of Business Research, 66(7), 904-909.

Albert, Noel, Merunka, Dwight, and Valette-Florence, Pierre (2009), The Feeling of Love Toward a Brand: Concept and Measurement, Advances in Consumer Research, Vol. 36, pp. 300-307.

Anderson, J. C., \& Gerbing, D. W. (1988). Structural equation modelling in practice: A review and recommended two-step approach. Psychological Bulletin, 103(3),411-423.

Aron, Arthur and Westbay, Lori (1996). Dimensions of the Prototype of Love. Journal of Personality \& Social Psychology, Vol. 70 (3), pp. 535-551.

Baek, T. H., Kim, J., \& Yu, J. (2010). The Differential Roles of Brand Credibility and Brand Prestige in Consumer Brand Choice. Psychology \& Marketing, 27, 662-678.

Bagozzi, R. P. (1992). The self-regulation of attitudes, intentions, and behavior. Social Psychology Quarterly, 55(2): 178-204.

Bagozzi, R. P., \& Dholakia, U. M. (2006). Antecedents and purchase consequences of customer participation in small group brand communities. International Journal of Research in Marketing, 23(1), 45-61. 
Bagozzi, R. P., Batra, R., \& Ahuvia, A. C. (2016). Brand Love: development and validation of a practical scale. Marketing Letters, 28, 1-14.

Batra, R., Ahuvia, A., \& Bagozzi, R. P. (2012). Brand Love. Journal of Marketing, 76, 1-16.

Bearden, W. O., \& Etzel, M. J. (1982). Reference group influence on product and brand purchase decisions. Journal of consumer research, 9(2), 183-194.

Belk, Russell W. (1988), "Possessions and the Extended Self," Journal of Consumer Research, 15 (2), 139-68.

Bhattacharya, C. B., \& Sen, S. (2003). Consumer-company identification: A framework for understanding consumers' relationships with companies. Journal of Marketing, 67(2), 76-88.

Bıçakcıŏlu, N., İpek, İ., \& Bayraktaroğlu, G. (forthcoming). Antecedents and outcomes of brand love: the mediating role of brand loyalty. Journal of Marketing Communications.Brakus, J. J., Schmitt, B. H., \& Zarantonello, L. (2009). Brand Experience: What Is It? How Is It Measured? Does It Affect Loyalty? Journal of Marketing, 73(3), 52-68.

Breivik, E., \& Thorbjørnsen, H. (2008). Consumer brand relationships : An investigation of two alternative models. Journal of Academy of Marketing Science, 36, 443-472.

Brewer, M. B. (1991). The social self: On being the same and different at the same time. Personality and social psychology bulletin, 17(5), 475-482.

Brucks, M., Zeithaml, V. A., \& Naylor, G. (2000). Price and brand name as indicators of quality dimensions for consumer durables. Journal of the Academy of Marketing Science, 28(3), 359-374.

Carpenter, G. S., \& Nakamoto, K. (1989). Consumer preference formation and pioneering advantage. Journal of Marketing Research, 26(3), 285-298.

Carpenter, G. S., Glazer, R., \& Nakamoto, K. (1994). Meaningful brands from meaningless differentiation: The dependence on irrelevant attributes. Journal of Marketing Research, 339-350.

Carroll, B. A., \& Ahuvia, A. C. (2006). Some antecedents and outcomes of brand love. Marketing Letters, 17(2), 79-89.

Chan, K.W., Yim, C.K., \& Lam, S.S. (2010). Is customer participation in value creation a double-edged sword? Evidence from professional financial services across cultures. Journal of Marketing, 74(3), 48-64.

Chaudhuri, Arjun, \& Mark Ligas (2009). Consequences of value in retail markets. Journal of Retailing, 85 (3), 406-419.

Chernev, A. (2004). Goal-attribute compatibility in consumer choice. Journal of Consumer Psychology, 14(1), 141-150.

Childers, T. L., Carr, C. L., Peck, J., \& Carson, S. (2001). Hedonic and utilitarian motivations for online retail shopping behavior. Journal of Retailing, 77(4), 511-535.

Cronin Jr, J. J., Brady, M.K., \& Hult, G.T.M. (2000). Assessing the effects of quality, value, and customer satisfaction on consumer behavioral intentions in service environments. Journal of Retailing, 76(2), 193-218.

Day, G. S. (1994). The capabilities of market-driven organizations. Journal of Marketing, 58(4), 37-52. 
Delgado-Ballester, E., \& Munuera-Alemán, J. L. (2001). Brand trust in the context of consumer loyalty. European Journal of Marketing, 35(11/12), 1238-1258.

Deshpande, R., \& Farley, J. U. (1993). Corporate culture customer orientation, and innovativeness in Japanese firms: A quadrad analysis. Journal of Marketing: A quarterly publication of the american marketing association, 57(1), 23-37.

Dhar, R., \& Sherman, S. J. (1996). The effect of common and unique features in consumer choice. Journal of Consumer Research, 193-203.

Dhar, R., \& Wertenbroch, K. (2000). Consumer choice between hedonic and utilitarian goods. Journal of Marketing Research, 37(1), 60-71.

Dodds, W. B., Monroe, K. B., \& Grewal, D. (1991). Effects of price, brand, and store information on buyers' product evaluations. Journal of Marketing Research, 307-319.

Dodds, W. B. (1991). In search of value: How price and store name information influence buyers' product perceptions. Journal of Services Marketing, 5(3), 27-36.

Dubois, B., \& Czellar, S. (2002). Prestige brands or luxury brands? An exploratory inquiry on consumer perceptions. Proceedings of the European Marketing Academy 31st Conference, University of Minho, Portugal.

Dutton, J. E., Dukerich, J. M., \& Harquail, C. V. (1994). Organizational images and member identification. Administrative science quarterly, 239-263.

Erdem, T., \& Swait, J. (1998). Brand equity as a signaling phenomenon. Journal of consumer Psychology, 7(2), 131-157.

Erdem, T., \& Swait, J. (2004). Brand credibility, brand consideration, and choice. Journal of Consumer Research, 31(1), 191-198.

Erdem, T., Swait, J., \& Valenzuela, A. (2006). Brands as Signals : A Cross-Country. Journal of Marketing, 70(January), 34-49.

Fang, E. (2008). Customer Participation and the Trade-Off Between New Product Innovativeness and Speed to Market. Journal of Marketing, 72(July), 90-104.

Fehr, Beverley and James A. Russell (1991), "The Concept of Love Viewed from a Prototype Perspective," Journal of Personality and Social Psychology, 60 (3), 425-38.

Fetscherin, Marc and Heinrich, Daniel (2015), "Consumer brand relationships research: A bibliometric citation meta-analysis," Journal of Business Research, 68, 380-390.

Fornell, C., \& Larcker, D. F. (1981). Evaluating structural equation models with unobservable variables and measurement error. Journal of Marketing Research, (18), 39-50.

Fournier, S. (1998). Consumers and Their Brands: Developing Relationship Theory in Consumer Research. Journal of Consumer Research, 24, 343-373.

Franke, N., \& Schreier, M. (2008). Product uniqueness as a driver of customer utility in mass customization. Marketing Letters, 19(2), 93-107.

Geuens, M., Weijters, B., \& De Wulf, K. (2009). A new measure of brand personality. International Journal of Research in Marketing, 26(2), 97-107.

Golder, P. N., Mitra, D., \& Moorman, C. (2012). What Is Quality? An Integrative Framework of Processes and States. Journal of Marketing, 76(July), 1-23. 
Haberland, G. S., \& Dacin, P. A. (1992). The development of a measure to assess viewers' judgments of the creativity of an advertisement: A preliminary study. Advances in Consumer Research, 19(1), 817-825.

Han, J. K., Kim, N., \& Srivastava, R. K. (1998). Market orientation and organizational performance: Is innovation a missing link? The Journal of Marketing, 62(october), 3045 .

Hauser, J. R., \& Wernerfelt, B. (1990). An Evaluation Cost Model of Consideration Sets. The Journal of Consumer Research, 16(4), 393-408.

He, H., Li, Y., \& Harris, L. (2012). Social identity perspective on brand loyalty. Journal of Business Research, 65(5), 648-657.Hirschman, E. C., \& Holbrook, M. B. (1982). Consumption: Emerging Concepts. Journal of Marketing, 46(3), 92-101.

Holbrook, M. B., \& Hirschman, E. C. (1982). The Experiential Aspects of Consumption: Consumer Fantasies, Feelings, and Fun. Journal of Consumer Research, 9(2), 132-40.

Homburg, C., Wieseke, J., \& Hoyer, W. D. (2009). Social identity and the service-profit chain. Journal of Marketing, 73(2), 38-54.

Iacobucci, D., \& Ostromn, A. (1996). Commercial and interpersonal relationships; Using the structure of interpersonal relationships to understand individual-to-individual, individual-to-firm, and firm-to-firm relationships in commerce. International Journal of Research in Marketing, 13(1), 53-72.

Keller, K. L. (2003). Brand Synthesis : The Multidimensionality of Brand Knowledge. Journal of Consumer Research, 29, 595-600.

Keller, K. L., \& Lehmann, D. R. (2006). Brands and Branding : Research Findings and Future Priorities. Marketing Science, 25(6), 740-759.

Kirmani, A., \& Zeithaml, V. (1993). Advertising, perceived quality, and brand image. In A. L. Biel \& D. A. Aaker (eds), pp. 143-161. Hillsdale, NJ: Lawrence Erlbaum Associates.

Kotler, P. (2003), Marketing management, International Edition, $11^{\text {th }}$ Ed. New Jersey: PrenticeHall.

Kohli, A. K., \& Jaworski, B. J. (1990). Market Orientation: The Construct, Research Propositions, and Managerial Implications. Journal of Marketing, 54, 1-18.

Kunz, Werner, Bernd Schmitt, and Anton Meyer (2011). "How does perceived firm innovativeness affect the consumer?" Journal of Business Research 64.8 (2011): 816822.

Kwak, L. E., \& Sojka, J. Z. (2010). If they could see me now: Immigrants' use of prestige brands to convey status. Journal of Consumer Marketing, 27(4), 371-380.

La, V., Patterson, P., \& Styles, C. (2009). Client-perceived performance and value in professional B2B services: An international perspective. Journal of International Business Studies, 40(2), 274-300.

Lam, S. K., Ahearne, M., Mullins, R., Hayati, B., \& Schillewaert, N. (2013). Exploring the dynamics of antecedents to consumer-brand identification with a new brand. Journal of the Academy of Marketing Science, 41(2), 234-252.

Levy, S. J. (1959). Symbols for sale. Harvard business review, 37(4), 117-124.

Lindell, M. K., \& Whitney, D. J. (2001). Accounting for common method variance in crosssectional research designs. Journal of Applied Psychology, 86(1), 114-121. 
Malär, Lucia, Harley Krohmer, Wayne D. Hoyer, Bettina Nyffenegger (2011) Emotional Brand Attachment and Brand Personality: The Relative Importance of the Actual and the Ideal Self. Journal of Marketing, 75(4): 35-52.

Malär, L., Nyffenegger, B., Krohmer, H., \& Hoyer, W. D. (2012). Implementing an intended brand personality: a dyadic perspective. Journal of the Academy of Marketing Science, 40(5), 728-744.

Marzocchi, G., Morandin, G., \& Bergami, M. (2013). Brand communities: loyal to the community or the brand? European Journal of Marketing, 47(1/2), 93-114.

Maxham III, J. G., \& Netemeyer, R. G. (2002). A Longitudinal Study of Complaining Custorners'Evaluations of Multiple Service Failiures and Recovery Efforts. Journal of Marketing, 66, 57-71.

McAlexander, J. H., Schouten, J. W., \& Koenig, H. F. (2002). Building brand community. Journal of Marketing, 66(1), 38-54.

Moliner, M. a., Sánchez, J., Rodríguez, R. M., \& Callarisa, L. (2007). Perceived relationship quality and post-purchase perceived value. European Journal of Marketing, 41 (11/12), 1392-1422

Moorman, C. (1995). Organizational Market Information Processes: Cultural Antecedents and New Product Outcomes. Journal of Marketing Research, XXXII(August), 318-335.

Netemeyer, R. G., Krishnan, B., Pullig, C., Wang, G., Yagci, M., Dean, D., and Wirth, F. (2004). Developing and validating measures of facets of customer-based brand equity. Journal of Business Research, 57(2), 209-224.

Oliver, Richard L. (1997), Satisfaction: A behavioral perspective on the consumer. New York: Irwin/McGraw-Hill.

Parasuraman, A. (1997). Reflections on gaining competitive advantage through customer value. Journal of the Academy of marketing Science, 25(2), 154-161.

Park, C. W., Jaworski, B. J., \& Maclnnis, D. J. (1986). Strategic brand concept-image management. Journal of Marketing, 50(October), 135-145.

Park, C. W., Milberg, S., \& Lawson, R. (1991). Evaluation of brand extensions: The role of product feature similarity and brand concept consistency. Journal of consumer research, 185-193.

Podsakoff, Philip M., Scott B. MacKenzie, Jeong-Yeon Lee, \& Nathan P. Podsakoff (2003). Common method biases in behavioral research: A critical review of the literature and recommended remedies. Journal of Applied Psychology, 88 (5), 879-903.

Rauschnabel, Philipp A, and Ahuvia, Aaron C. (2014), "You're so lovable: Anthropomorphism and brand love," Journal of Brand Management 21, 372-395.

Rauschnabel, P. A., Krey, N., Babin, B. J., \& Ivens, B. S. (2016). Brand management in higher education: The University Brand Personality Scale. Journal of Business Research, 69(8), 3077-3086.

Roberts, K. (2005), Lovemarks: The Future Beyond Brands, New York, NY: PowerHouse Books.

Rosch, Eleanor (1978). Principles of Categorization. In Rosch, Eleanor, \& Lloyd, Barbara B. (eds), Cognition and categorization 27-48, Hillsdale, NJ: Lawrence Erlbaum.Roy, P., 
Khandeparkar, K., \& Motiani, M. (2016). A lovable personality: The effect of brand personality on brand love. Journal of Brand Management,(May).

Roy, S. K., Eshghi, A. A., \& Sarkar, A. (2012). Antecedents and consequences of brand love. Journal of Brand Management, 20(4), 325-332.

Stayman, D. M., Alden, D. L., \& Smith, K. H. (1992). Some effects of schematic processing on consumer expectations and disconfirmation judgments. Journal of Consumer Research, 19(2), 240-255.

Steenkamp, J. E. B. M., Batra, R., \& Alden, D. (2003). How perceived brand globalness creates brand value. Journal of International Business Studies,34(1), 53-65.

Sternberg, R. (1986). A triangular theory of love. Psychological Review, 93(2), 119-135.

Stokburger-Sauer, N., Ratneshwar, S., \& Sen, S. (2012). Drivers of consumer-brand identification. International Journal of Research in Marketing, 29, 406-418.

Subramaniam, M., \& Youndt, M. A. (2005). The influence of intellectual capital on the types of innovative capabilities. Academy of Management Journal,48(3), 450-463.

Swait, J., \& Erdem, T. (2007). Brand effects on choice and choice set formation under uncertainty. Marketing Science, 26(5), 679-697.

Thompson, C. J., Rindfleisch, A., \& Arsel, Z. (2006). Emotional branding and the strategic value of the Doppelgänger brand image. Journal of Marketing, 70(1), 50-64.

Tuan, Y. F. (1980). The significance of the artifact. Geographical Review, 462-472.

Vernuccio, M., Pagani, M., Barbarossa, C., \& Pastore, A. (2015). Antecedents of brand love in online network-based communities. a social identity perspective. Journal of Product \& Brand Management, 24(7).

Valta, K. S. (2013). Do relational norms matter in consumer-brand relationships? Journal of Business Research, 66(1), 98-104.

Vigneron, F., \& Johnson, L. W. (1999). A review and a conceptual framework of prestigeseeking consumer behavior. Academy of Marketing Science Review, vol e nº???, 1, 1-15.

Ülkümen, G., Chakravarti, A., \& Morwitz, V. G. (2010). Categories create mind-sets: The effect of exposure to broad versus narrow categorizations on subsequent, unrelated decisions. Journal of Marketing Research, 47(4), 659-671.

Wernerfelt, B. (1988). Umbrella branding as a signal of new product quality: An example of signalling by posting a bond. The Rand Journal of Economics, 19(3), 458-466.

Woodruff, R. B. (1997). Customer value: The next source for competitive advantage. Journal of the Academy of Marketing Science, 25(2), 139-153.

Yim, C. K., Tse, D. K., \& Chan, K. W. (2008). Strengthening customer loyalty through intimacy and passion: Roles of customer-firm affection and customer-staff relationships in services. Journal of Marketing Research, 45(6), 741-756.

Yoon, D. N. (2015). How IKEA Designs Its Brand Success. Accessed on the $13^{\text {th }}$ of January 2017,http:/www.forbes.com/sites/deniselyohn/2015/06/10/how-ikea-designs-its-brandsuccess/\#5b4432013901.

Zhao, X., Lynch, J.G. and Chen, Q. (2010). Reconsidering Baron and Kenny: Myths and truths about mediation analysis. Journal of Consumer Research, 37(2), 197-206. 
Zeithaml, V. A. (1988). Consumer perceptions of price, quality, and value: A means-end model and synthesis of evidence. Journal of Marketing, 52(3), 2-22. 
Figure 1:

\section{Conceptual model}

\section{Exogenous variables $\quad$ Mediating variables $\quad$ Outcome variables}

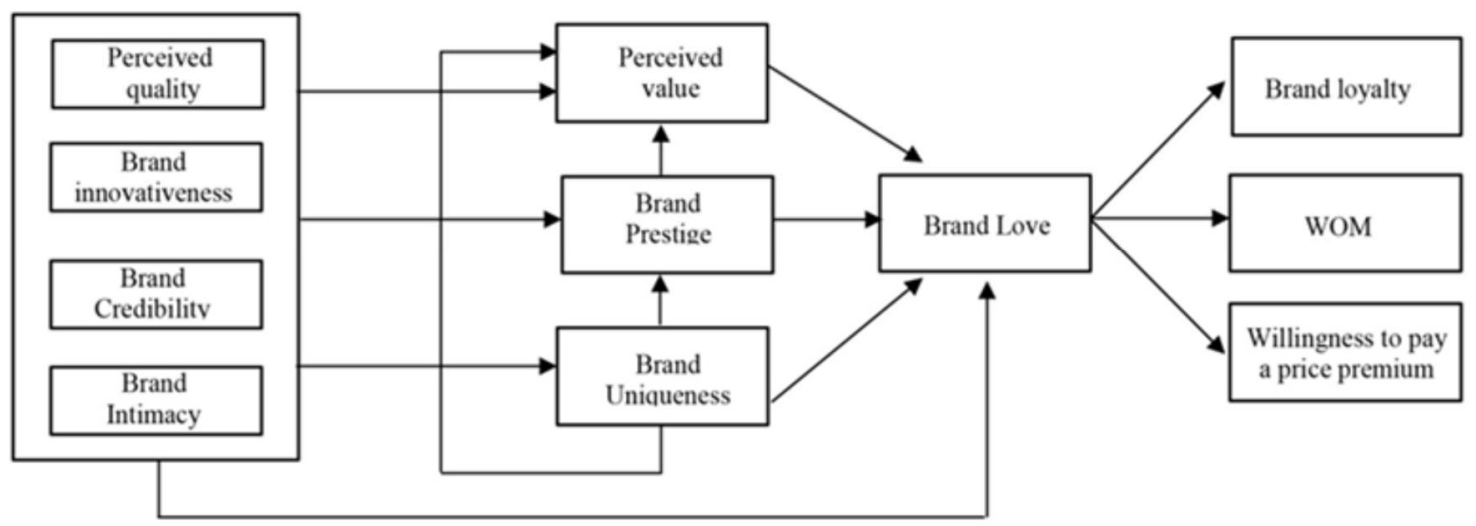

\section{Figure2:}

\section{Results}

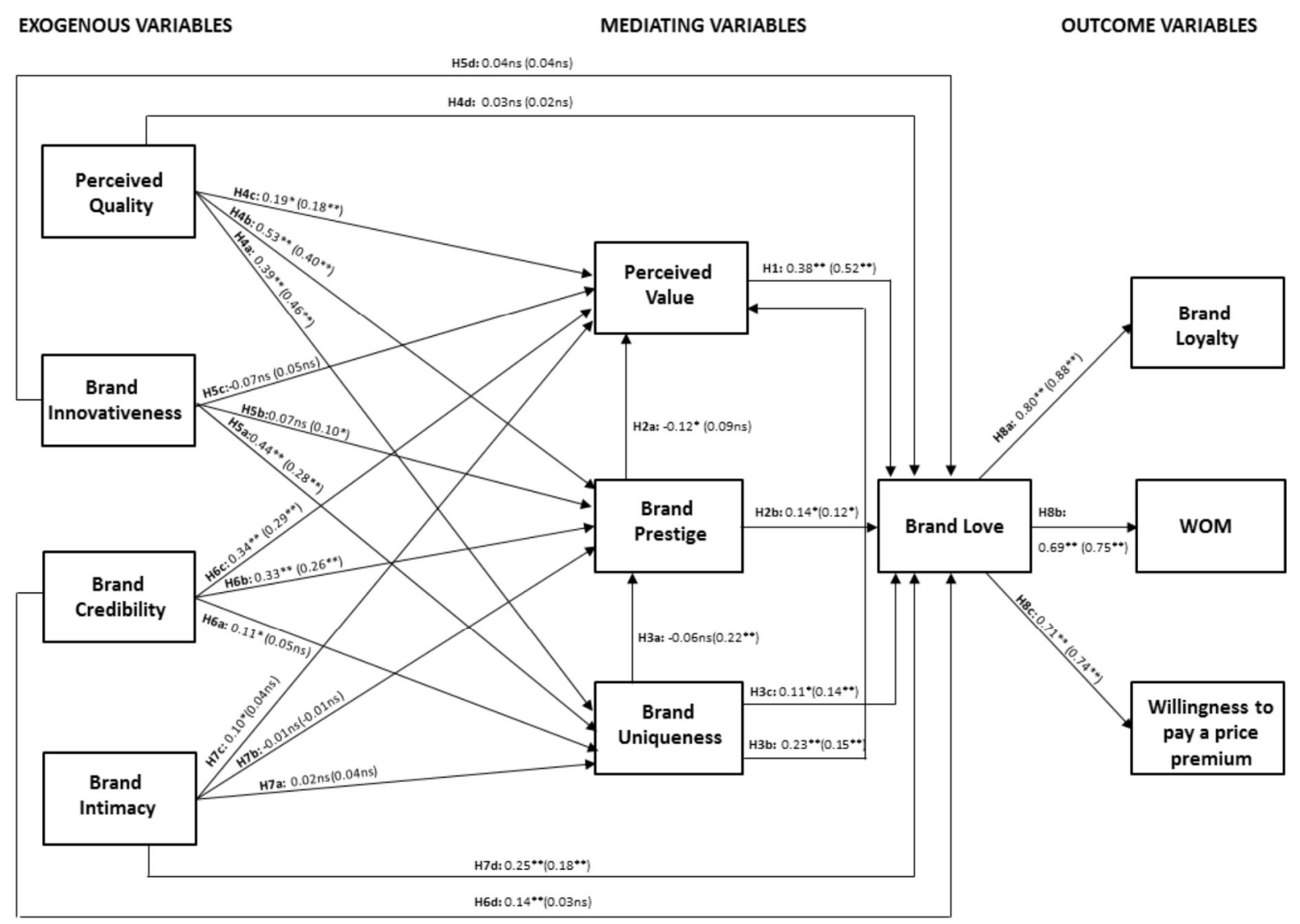

Note: Results of sample 2 in brackets. 